\title{
APLIKASI TEKNOLOGI INFORMASI DALAM PENGELOLAAN ARSIP
}

Oleh :

Sugi Rahayu

FIS UNY

\section{Abstrak}

Arsip sebagai produk kegiatan organisasi volumenya dari waktu ke waktu terus bertambah, sehingga apabila tidak dikelola dengan baik akan menimbulkan berbagai persoalan menyangkut keamanan, pemanfaatan, penyimpanan, perawatan, dan sebagainya. Arsip akan berperan lebih berarti dalam kehidupan organisasi bilamana para pimpinan organisasi menganggap penting penyelenggaraan dan pengelolaan arsip.

Selama ini orang mengartikan arsip dalam pengertian sempit, akibatnya arsip semata-mata hanyalah dianggap dan diperlakukan sebagai dokumen yang cukup untuk disimpan saja. Dalam kehidupan organisasi, arsip dapat diolah menjadi informasi yang berguna untuk manajemen, dukungan terhadap sistem perencanaan, dukungan terhadap sistem pengendalian, dukungan terhadap sistem penilaian, dan manajer.

Sejalan dengan perkembangan teknologi informasi yang berdampak pada perubahan konsep yang mendasar dari pengertian arsip dan pengelolaannya, maka membawa implikasi pokok berupa perubahan konsep tentang petugas kearsipan (arsiparis). Tugas arsiparis tidak lagi sekedar melaksanakan kegiatan collecting, recording and storing data, melainkan harus mampu menjadi data analyst dan manajer informasi dalam organisasi

Kata kunci : teknologi, informasi, arsip, pengelolaan

\section{Pendahuluan}

Pada tanggal 30 Juni 2005 Kompas memuat berita yang berjudul "Arsip Polda Berantakan". Berita tersebut cukup mengagetkan, betapa tidak pada era teknologi informasi yang begini canggih arsip sebuah lembaga pelayanan publik yang sangat besar seperti Polda Metro Jaya mengalami persoalan dalam pengelolaannya. Dalam berita tersebut dikatakan bahwa selama kurun waktu 30 tahun, dari 1970 sampai 2005 , penataan arsip kendaraan bermotor yang berdomisili di 
sampai 2005, penataan arsip kendaraan bermotor yang berdomisili di Jakarta berantakan dan terpencarpencar. Jutaan arsip tak tertata dalam ruang bawah tanah. Akibatnya pelayanan balik nama, mutasi, dan perpanjangan lama. Bundel arsip yang berjumlah 5-10 juta itu baru sebagian kecil yang ter-input dalam komputer, sehingga tidak mudah bagi petugas untuk mencari data kendaraan.

Keadaan seperti itu mungkin juga dialami oleh lembaga pelayanan publik yang lain. Selama ini masih ada anggapan bahwa arsip sebagai sumber informasi belum dianggap penting untuk dikelola dengan baik. Padahal arsip timbul sebagai akibat dari pelaksanaan tata usaha yang mengolah data, fakta, keterangan menjadi informasi. Arsip sebagai sumber informasi dan sumber ingatan bagi suatu lembaga, kehadirannya mutlak diperiukan.

Arsip memiliki tiga dimensi waktu, yaitu: masa lalu, masa kini, dan masa depan. Arsip masa lalu merupakan rekaman informasi segala hal dalam berbagai media (kertas, kaset, film, disket, dsb.) di masa lalu yang penting bagi sejarah kehidupan bangsa. Arsip masa kini digunakan untuk penunjang kegiatan pekerjaan sehari-hari. Keputusan pimpinan suatu lembaga tidak bisa tepat apabila tidak didukung data dari arsip dinamis dan aktif. Sedangkan arsip masa depan sangat membantu kesukse- san pembangunan di era globalisasi dan informasi seperti sekarang ini. $\mathrm{Hal}$ ini sesuai dengan hakikat arsip seperti dikemukakan Noerhadi M., Kepala Arsip Nasional, bahwa melalui arsipnya suatu bangsa dapat memandang ke belakang ke masa lalunya dan menggaii pengalamannya sambil sekaligus memandang ke depan untuk merencanakan masa depannya (1997: 9).

Salah satu keberhasilan lembaga atau organisasi terletak pada sistem informasi yang dikelola dengan baik. Arsip akan berperan lebih berarti da'am kehidupan organisasi bilamana para pimpinan organisasi menganggap penting penyelenggaraan dan pengelolaan arsip secara semestinya. Selama ini banyak orang menjabarkan pengertian arsip dalam pengertian sempit. Akibatnya kebanyakan orang menganggap dan memperlakukan arsip semata-mata hanyalah sebagai dokumen yang cukup untuk disimpan saja. Tidak jarang penyimpanan arsip hanya ditumpuk atau dimasukkan dalam suatu tempat misalnya almari secara acak dan terlihat rapi, sehingga pada waktu diperlukan kembali tidak cepat diketemukan. Ini berarti tujuan pengelolaan arsip tidak tercapai. Agar hakikat arsip tersebut dapat terealisasi maka perlu perubahan cara pandang terhadap pengertian arsip. Arsip semestinya tidak saja diartikan sebagai media rekam secara fisik tetapi yang terpenting adalah kandu- 
ngan informasi yang terkandung di dalamnya.

\section{Arsip sebagai Sumber Informasi}

Memasuki era informasi seperit sekarang ini, peran informasi menjadi sangat penting dan mahal. Informasi perlu dikelola dengan baik karena informasi merupakan sumberdaya yang sangat penting bagi semua lembaga baik pemerintah maupun swasta, dan arsip adalah sumber informasi utama yang tersedia. Arsip merupakan produk dari berbagai kegiatan yang telah dilaksanakan oleh organisasi, sehingga volumenya dari waktu ke waktu akan bertambah. Apabila arsip tidak dikelola dengan baik akan menimbulkan berbagal persoalan menyangkut keamanan, pemanfaatan, penyimpana, perawatan, dan sebagainya.

Berdasarkan fungsinya arsip dibedakan menjadi dua, yaitu arsip statis dan dinamis (The Liang Gie, 1996: 218). Arsip seharusnya diperlakukan secara seimbang tanpa memandang fungsi arsip yang satu lebih tinggi nilainya dibandingkan arsip yang lain. Frekuensi penggunaan arsip statis yang lebih sedikit dibandingkan dengan arsip dinamis dalam kegiatan organisasi sehari-hari, tidak berarti arsip statis memiliki nilai yang lebih rendah. Pada dasarnya nilai guna arsip statis dan dinamis ini sama, yang berbeda hanyalah fungsinya. Arsip statis sering tidak diperhatikan dalam pengelolaannya, se- hingga apabila sewaktu-waktu diperlukan tidak dapat diketemukan secara cepat. Hal ini seperti kasus yang terjadi di Polda Metro Jaya.

Atas dasar itulah maka arsip di samping dikelola dengan baik perlu juga dilestarikan sehingga dapat didayagunakan baik sebagai informasi maupun sebagai landasan akuntabilitas. Tujuan dari pengelolaan dan pelestarian arsip adalah sebagai: (1) sumber informasi, (2) landasan pengambilan keputusan, (3) rekaman kebijakan dan preseden yang telah ada, (4) memori organisasi, (5) untuk akuntabilitas dan auditing, (6) jaminan kepastian hukum dan komitmen terhadap keputusan yang telah diambil, (7) untuk penegakan hukum terhadap keputusan pengadilan, dan (8) untuk penunjang penelitian (Noerhadi, M., 1997: 4). Pembahasan selanjutnya lebih menekankan kepada arsip sebagai sumber informasi tentunya dengan tidak melupakan maksud dan tujuan yang lain.

Arsip sebagai sumber utama informasi merupakan sumberdaya pendukung bagi penyelenggaraan manajemen. Suatu organisasi dalam kegiatan perencanaan sampai dengan kegiatan pengawasan untuk mencapai tujuan selain akan menghasilkan banyak arsip tetapi juga membutuhkan dukungan arsip, karena arsip merupakan landasan bagi perumusan dan pelaksanaan kebijakan secara konsisten, mempertahankan akuntabilitas, melindungi hak 
karyawan atau warga negara, dan bahkan memelihara kesinambungan pengembangan ilmu pengetahuan. Dengan tibanya era informasi, maka keperluan untuk mengelola arsip, terlepas dari apakah arsip tradisional (kertas) maupun elektronik, akan tetap menjadi unsur penentu bagi keberhasilan organisasi dalam mencapai tujuannya.

\section{Aplikasi Teknologi Informasi dalam Pengelolaan Arsip}

Saat ini dunia kearsipan berada pada masa transisi. Masa transisi yang dimaksudkan adalah masa transisi antara dua era, yaitu: Pertama, era informasi. Informasi mulai menduduki dan memainkan peranan yang sangat penting dan menentukan di dalam kehidupan manusia. Kedua, masa transisi teknologi baru yaitu teknologi yang berbasis komputer. Kedua era ini sangat mempengaruhi dunia kearsipan, baik dipandang dari sudut ilmu kearsipan (konseptual) itu sendiri maupun dari sudut manajemennya.

Secara sederhana teknologi informasi dapat dikatakan sebagai ilmu yang diperlukan untuk mengelola informasi agar informasi itu dapat dicari dengan mudah, cepat, dan akurat. Isi dari ilmu ini dapat berupa teknik-teknik dan prosedur untuk menyimpan informasi secara efisien dan efektif (Bambang Sudaryatno, 2004: 1). Di sisi lain Yogiyanto memiberikan definisi informasi adalah da- ta yang diolah menjadi (1) bentuk yang lebih berguna dan lebih berarti bagi yang menerimanya, (2) menggambarkan suatu kejadian (event) dan kesatuan nyata (fact dan entity), (3) digunakan untuk pengambilan keputusan (2000: 25). Dalam pengelolaan arsip teknologi informasi dapat diaplikasikan antara lain dalam penyiapan dokumen, pendistribusian dokumen dan informasi melalui e-mail, intranet dan internet, penyimpanan dan penemuan kembali arsip/dokumen yaitu dengan teks berkode komputer dan teknologi microform, dan pendayagunaan arsip sebagai sumber informasi dalam pengembangan sistem informasi manajemen (SIM).

Selama ini perhatian terhadap arsip lebih kepada arsip yang berupa kertas. Padahal seiring dengan pesatnya perkembangan teknologi, arsip mempunyai cakupan makna yang lebih luas. Saat ini sudah mulai diterapkan budaya paperless dalam kegiatan organisasi. Sebagai salah satu contoh, di UNY dalam berbagai kegiatan kepanitiaan sudah mengurangi undangan, laporan, ataupun curah pendapat dengan menggunakan kertas.

Lembaga Administrasi Negara (LAN) mengartikan arsip sebagai kertas naskah, buku, foto, film, mikrofilm, rekaman suara, gambar, peta, bagan, dokumen-dokumen tertentu dalam segala bentuk dan sifatnya baik asli maupun salinan yang diha- 
silkan atau diterima oleh organisasi. Pengertian arsip ini luas, karena lidak hanya surat-surat dalam bentuk kertas, tetapi meliputi segala hal karena kegunaannya sehingga perlu disimpan.

Pengelolaan arsip selama ini masih dilakukan secara sangat teknis dalam arti bahwa pengelolaan arsip tetap berupaya untuk memperhatikan ciri-ciri pengelolaan arsip yaitu isi, struktur, dan konteks melalui perawatan terhadap media rekamnya saja. Penekanan pengelolaan arsip dari sudut fisik ini hanya dapat diterapkan pada arsip tradisional baja. Sebagai akibat dari peningkalan peranan informasi dalam masyarakat dunia, maka peranan arsip pun meningkat. Hal ini disebabkan karena arsip merupakan salah satu media rekam informasi. Sebagai media rekam informasi, maka pengelolaan arsip tidak lagi terpaku pada segl teknis yaitu bagaimana menata dan menemukan kembali, melainkan dari sisi peranan arsip sebagai informasi sehingga nilai guna arsip akan bertambah.

Di dalam dunia yang semakin kompleks ini, kegiatan apapun tidak dapat lagi mengandalkan ingatan pelaksana atau pelakunya karena ketorbatasannya sebagai manusia. Mereka memerlukan bantuan teknologi informasi agar tidak tertinggal oleh derasnya arus informasi. Perubahan lain yang harus dipikirkan tentang arsip sebagai informasi adalah bah- wa informasi itu dapat juga digunakan oleh orang lain. Informasi akan jauh lebih meningkat nilai gunanya apabila dikaitkan dengan informasi yang lain. Semakin luas jaringan informasi itu, akan semakin tak terbatas nilai gunanya.

Disebutkan bahwa perkembangan teknologi informasi saat ini sangat mempengaruhi dunia kearsipan, baik dipandang dari sudut ilmu kearsipan itu sendiri maupun dari sudut manajemennya. Akibatnya, terjadi perubahan yang sangat mendasar (secara konseptual) mengenai pengertian arsip, bahwa sejak penciptaan maupun penerimaan, informasi dikomunikasikan lewat electronic mail (E-Mail) tanpa hard copy atau surat-surat melalui pos. Arsip seperti ini yang diciptakan, disimpan, dan dikirimkan atau disajikan dengan perantaraan komputer menjadi tidak dapat dibaca tanpa bantuan komputer atau tanpa dicek oleh komputer. Dari uraian di atas dapat dikatakan bahwa dunia kearsipan tidak mungkin tidak harus mengikuti perkembangan teknologi informasi karena saat ini informasi dibutuhkan dengan cepat dan akurat.

Aplikasi teknologi informasi dalam pengelolaan arsip diawali dengan arsip direkam pada media yaitu komputer. Sistem penyimpanan dan penemuan kembalinya cukup dikerjakan sekali dan untuk seterusnya seolah-olah berjalan dengan sendirinya karena pekerjaan tangan penge- 
lola arsip diambil alih oleh program komputer. Oleh karena arsip direkam dalam komputer atau disebut sebagai arsip elektronik, maka informasi yang ada dalam rekaman itu menjadi rawan terhadap manipulasi. Informasi itu dengan relatif mudah dihilangkan, dikurangi atau ditambah, bahkan diganti sama sekali.

Karena informasi yang terkandung dalam arsip elektronik ini mudah diakses, maka pengamanan secara fisik menjadi lebih rumit. Pesatnya perkembangan teknologi informasi, seperti sarana jaringan internet misalnya, memungkinkan orang untuk membuka arsip atau membuka informasi yang terkandung di dalamnya dalam jarak yang tak berbatas (borderless). Selain pengambilan informasi, arsip juga dapat dikirimkan, di copy, atau bahkan diolah pada saat yang cepat. Bahkan saat ini dengan peningkatan kemampuan komputer untuk menyimpan dan mengolah data secara multimedia, maka pengertian arsip media baru pun menjadi kabur. Hal ini disebabkan karena berbagai arsip dengan media baru itu seperti misalnya rekaman suara, foto, atau film, bersama-sama dengan arsip kertas, melalui teknologi digital informasinya dapat disimpan atau direkam dalam satu media saja, yaitu sebagai arsip elektronik.

Uraian di atas adalah terkait dengan pengelolaan arsip ditinjau dari sisi arsip sebagai sumber infor- masi. Masalah akan timbul apabila dilihat dari sisi lain, seperti misalnya sebagai barang bukti. Sebagai contoh, misalnya arsip itu diperlukan di pengadilan sebagai barang bukti. Apakah barang bukti berupa print out dapat diterima sebagai bukti yang sah dan masih banyak lagi masalah krusial yang muncul dalam dunia kearsipan.

Pengelolaan arsip sebenarnya bertumpu pada dua pendekatan (Noerhadi, M.: 1997: 16)

1. Pengelolaan informasi

Informasi perlu dikelola, dikembangkan, diolah dan seterusnya. Ini menjadi tugas arsiparis.

2. Pengguna informasi

Pengelolaan ini diarahkan agar informasi dapat didayagunakan secara optimal oleh pengguna.

Penggunaan informasi adalah untuk:

- Manajemen. Setiap manajemen menuntut efisensi dan produktivitas kerja yang tinggi, sehingga sangat tergantung kepada kelengkapan, kemutakhiran, dan kecepatan perolehan informasi. Inormasi dibutuhkan oleh semua lini manajemen, yaitu perencanaan, pelaksanaan, dan pengawasan. Ditinjau dari sudut ini pengelolaan arsip ditujukan untuk menyediakan informasi yang diolah dari sumbernya yaitu arsip dan yang kemudian disajikan bagi keperluan perencana- 
an, pelaksanaan, dan pengawasan.

- Dukungan terhadap Sistem Perencanaan. Proses perencanaan yang mengikuti urutan tradisional di mana setiap produk informasi diteruskan dari satu tangan ke tangan yang lain dipersingkat dan disederhanakan dengan bantuan sistem informasi manajemen. Dengan demikian proses perencanaan menjadi lebih cepat, optimal, dan tepat sasaran.

- Dukungan terhadap Sistem Pengendalian. Pola ini mengikuti pengendalian umpan balik di mana hasil-hasil pelaksanaan di lapangan dikumpulkan dan kemudian dievaluasi dengan tolok ukur yang ada dalam rencana. Selanjutnya data penyimpangan merupakan informasi yang disampaikan kepada pimpinan untuk tindakan koreksi.

- Dukungan terhadap Sistem Penilaian. Dukungan dilakukan untuk mengetahui adanya penyimpangan dan tolok ukur penilaian terhadap penyimpangan tersebut. Sistem penilaian merupakan proses analisis dan evaluasi atas pelaksanaan peraturan dan pencapaian sasaran.

- Manajer. Dengan peningkatan volume pekerjaan atau beban kerja dan kompleksitas tugas yang harus dilaksanakan, para manajer sering dihadapkan pada keadaan dimana ia harus mengambil keputusan secara cepat dan akurat. Pengambilan keputusan ini memerlukan dukungan ketersediaan informasi yang utuh, akurat dan mutakhir. Tugas arsiparis dalam hal ini adalah menyajikan informasi yang diperlukan itu. Penyajian itu hanya dapat disampaikan kepada pejabat yang berhak.

Apabila pengelolaan arsip berjalan baik maka kesan bahwa birokrasi yang lamban, perencanaan yang terkotak-kotak dan pengambilan keputusan terasa kurang terkoordinasi dapat teratsi. Namun demikian dari sudut pengelolaan kearsipan itu sendiri, pencapaian keadaan pengelolaan yang demikian tidaklah mudah dan sederhana. Diperlukan perombakan struktur organisasi dan perubahan pola berfikir arsiparisnya.

Implikasi dari Aplikasi Teknologi Informasi dalain Pengelolaan Arsip

Keberhasilan pengelolaan arsip dalam suatu organisasi ditentukan oleh banyak faktor. Petugas kearsipan atau disebut arsiparis merupakan salah satu faktor yang menentukan kualitas pengelolaan arsip dalam suatu organisasi. Petugas kearsipan tidak hanya dituntut untuk memiliki wawasan dan latar bela- 
kang ilmu pengetahuan yang luas, melainkan juga harus selalu meningkatkan kemampuan dan pengetahuannya sesuai dengan perkembangan kondisi dan jenis arsip yang dikelola. Saat ini petugas kearsipan dituntut untuk menguasai kemampuan dan memiliki pengetahuan tentang teknologi informasi, terutama penguasaan teknologi komputer agar mampu mengembangkan program-program yang berkaitan dengan pengelolaan arsip yang menjadi bidang tugasnya.

Status petugas kearsipan yang bertanggung jawab terhadap pengelolaan arsip ditentukan oleh dua faktor, yaitu sistem organisasi yang digunakan dan besar kecilnya ukuran organisasi. Sistem pengorganisasian yang mendasarkan azas sentralisasi menghendaki pegawai yang bekerja khusus hanya menangani kearsipan saja, sedang pada kantor yang menganut azas desentralisasi, pegawai dapat melakukan pekerjaan lain di samping juga mengelola arsip (Zulkifli Amsyah, 1993: 199-200).

Terlepas dari sistem pengorganisasian yang digunakan oleh suatu organisasi, pengelolaan arsip harus ditangani oleh orang (arsiparis) yang profesional, tidak sekedar menjalankan pekerjaannya sebagai rutinitas, tetapi mampu berfikir inovatif guna mengembangkan alur kerja sehingga tercipta kondisi kearsipan yang tertib, teratur, sistematis, dan efisien.
Sejalan dengan perkembangan teknologi informasi yang berdampak pada perubahan konsep yang mendasar dari pengertian arsip dan pengelolaannya, maka perlu dilakukan perubahan konsep tentang petugas kearsipan. Anggapan bahwa pekerjaan di bidang kearsipan, seperti selama ini, yang hanya dimaknai sebagai pekerjaan yang bersifat rutin dari kertas ke kertas sampai menyimpan dan kirim mengirim surat/ dokumen lainnya, perlu diubah.

Rutinitas pekerjaan tersebut menyebabkan petugas kearsipan kehilangan inovasi, kreativitas, dan daya tanggap untuk mengubah dan menyempurnakan cara kerja mereka. Dalam keadaan seperti sekarang ini tidak dapat lagi ditolerir bahwa petugas kearsipan adalah pegawai yang ditugasi tanpa mempertimbangkan kemampuan di bidang kearsipan secara profesional karena dianggap bahwa pekerjaan pengelolaan arsip sebagai pekerjaan yang pasif yaitu mengatur dan menyimpan arsip. Kegiatan kearsipan baru dianggap aktif apabila arsip dibutuhkan. Jadi ada dorongan dari luar (faktor eksternal) yang membutuhkan.

Kearsipan belum merupakan lembaga atau kegiatan yang bersifat dan berkadar inner active dalam arti bahwa kearsipan masih berorientasi kepada customer service. Kondisi ini menghendaki dan menuntut petugas yang bergerak di bidang ke- 
arsipan mampu mengolah apa yang ada (data) untuk dijadikan sebagai informasi secara aktif dan tidak bersifat menunggu. Ke depan arsiparis adalah tenaga profesional pembuat informasi dan tidak lagi tonaga penyimpan dan pengatur data. Arsiparis adalah analis-analis data yang mampu mengubah data menjadi informasi.

Menurut Warsito Utomo (1997: 4). perpindahan dari peralatan dan aktivitas kearsipan yang "berdebu" menjadi peralatan atau aktivitas kearsipan yang "peka terhadap debu" menuntut revitalisasi peran dan pemberdayaan (empowering) petugas kearsipan (arsiparis). Meskipun pekerjaan kertas masih digunakan, tolapi makna dan fungsinya menjadi berubah tidak hanya sekedar collecting, recording, and storing, tetapi menjadi komponen atau aktivitas olaborator atau forwarder atau data analyst.

Petugas kearsipan harus dapat meletakkan aktivitasnya sebagai komponen yang memerlukan profeslonalisme tinggi, sehingga dapat mendudukkan profesi arsiparis dalam kategori yang "diperhitungkan" dan menarik. Tidak dipandang sebelah mata seperti sekarang ini. Untuk Ilu selain persyaratan-persyaratan yang harus dipenuhi sebagai toorang arsiparis seperti: ketrampilan, ketelitian, kerapian, kecerdasan, dan kepribadian, masih perlu ditambah kemampuan untuk menjadi data nalyst yang mau tidak mau harus menguasi teknologi informasi dan komunikasi (ICT).

Implikasi yang lain terkait dengan aplikasi teknologi informasi dalam pengelolaan arsip yang tidak kalah pentingnya adalah peralatan penyimpanan arsip. Kecepatan dalam penemuan kembali suatu arsip yang diperlukan ditentukan oleh ketersediaan dan kelengkapan peralatan, bentuk, dan kualitas peralatan penyimpanan arsip. Tidak tersedianya peralatan minimal yang layak dapat menimbulkan dampak terhadap kecepatan penemuan kembali arsip karena tidak menentunya letak penyimpanan dan pada akhirnya penemuan kembali arsip secara cepat dan tepat tidak terealisir.

Pemilihan terhadap peralatan penyimpanan arsip harus mempertimbangkan berbagai aspek agar peralatan tersebut berdaya guna. Salah satu pertimbangan yang perlu diperhatikan adalah model penyimpanan, apakah penyimpanannya secara horisontal (mendatar), vertikal (tegak), atau lateral (menyamping). Pertimbangan lain misalnya ditinjau dari segi keamanan arsip dari pencurian dan kerusakan oleh air, api, debu, kelembaban udara dan juga virus. Untuk arsip yang bersifat elektronik diperlukan peralatan yang canggih agar arsiparis dapat menganilisis dan akhirnya menyajikan data dengan cepat. 
Terkait dengan peralatan penyimpanan arsip, ruang penyimpanan arsip juga perlu mendapat perhatian, terlebih arsip elektronik. Ruang kearsipan hendaknya ditempatkan pada lokasi yang strategis sehingga mudah dijangkau oleh semua bagian yang ada dalam organisasi. $\mathrm{Hal}$ ini dimaksudkan untuk mengurangi hambatan waktu dalam menempuh jarak perjalanan menuju dan dari ruang arsip.

Semakin banyaknya peralatan elektronik sebagai akibat dari adanya arsip elektronik memerlukan kehadiran air conditioner (AC) dalam ruang arsip. AC merupakan alat yang dapat menyedot debu yang ada di dalam ruangan, sehingga ruangan terbebas dari debu. Debu merupakan salah satu penyebab kerusak.an arsip. Komponen yang ada pada $A C$ juga dapat diatur untuk menentukan tingkat kelembaban udara yang dibutuhkan. Dengan demikian ketersediaan $A C$ menjadi suatu keharusan untuk menjaga arsip dari kerusakan.

Peralatan penyimpanan arsip betapapun bagusnya tidak akan menghasilkan pengarsipan yang efisien apabila tidak didukung oleh sistem penyimpanan arsip yang tepat. Arsip sebagai sumber informasi yang dapat membantu melancarkan tugas pekerjaan dan menjadi dasar pertimbangan bagi pimpinan dalam mengambil suatu keputusan secara tepat mengenai suatu permasalahan yang sedang dihadapi perlu disimpan dan dikelola secara profesional. Letak arsip secara berkelompok maupun tunggal berada, ditentukan oleh sistem penyimpanan yang dipilih. Dari sistem penyimpanan inilah akan ditetapkan kelompok-kelompok sebagai dasar penempatannya.

Sistem penyimpanan arsip pada dasarnya adalah penyimpanan berdasar kata tangkap (caption) dari arsip yang disimpan baik berupa huruf (abjad) maupun angka yang disusun menurut urutan tertentu. Sistem penyimpanan yang berdasarkan urutan abjad adalah sistem nama, geografis, dan sistem subyek. Sedangkan yang berdasarkan urutan angka adalah sistem numerik, kronologis, dan sistem subyek numerik. Dalam hal ini, The Liang Gie menyebutkan bahwa sistem yang standar dalam penyimpanan arsip adalah meliputi: sistem abjad (alpabetic filing), pokok soal (subject filing), wilayah (geographic filing), nomor (numeric filing), dan tanggal (chronological filing) (1996:120-122).

Di antara kelima system tersebut masing-masing mempunyai kelebihan dan kekurangan. Untuk dapat menentukan sistem yang tepat harus diselaraskan dengan karakteristik dari arsip dan juga tidak terlepas dari bidang kerja organisasi yang bersangkutan. Jadi sistem yang tepat adalah sistem yang sesuai dengan tujuanserta masalah yang ditangani olen organisasi tersebut. Bahkan 
dalam suatu organisasi pun tidak ada suatu keharusan untuk menggunakan sistem tertentu secara seragam. Kesalahan penerapan sistem penyimpanan jelas akan berpengafuh torhadap tingkat kecepatan dalam penemuan kembali arsip baik arsip konvensional maupun elekIronik. Khusus untuk arsip elektronik, sistom penyimpanannya harus benar-benar jelas dan diikuti secara konsisten karena kalau tidak, bukan hanya tidak praktis untuk mencarinya malahan memakan waktu lama.

Dalam suatu organisasi yang besar dimana informasi yang diolah dan dimilikinya banyak dan beraneka ragam monyebabkan sulitnya menggunakan satu sistem penyimpanan lollontu, sehingga dalam praktik sehari-hari penerapan hanya satu sislom Jarang ditemui. Kombinasi dari berbagai sistem penyimpanan dapat mombantu memudahkan pengelolaan arsip.

\section{Ponutup}

Perkembangan teknologi informasi tolah membawa dampak perubahan terhadap dunia kearsipan, baik secara konseptual dipandang dari sudut ilmu kearsipan itu sendiri maupun dari sudut manajemennya. Arsip yang semula hanya disimpan, dirawat, dan disampaikan saat diperlukan yang menjadikan pengelolaan arsip menjadi statis, mahal dan pada gilirannya kurang dihargai lolalı mengalami perubahan yang signifikan. Dari sisi sumberdaya manusianya (arsiparis), pada era teknologi informasi ini tidak hanya bertindak sebagai penjaga arsip, melainkan sebagai tenaga profesional yang secara aktif mampu mengolah dan menyajikan informasi. Penyajian itu mereka laksanakan sesuai kebutuhan, apakah untuk perencanaan, pelaksanaan, ataukah bagi pengawasan. Arsiparis mengelola arsip dalam arti menghimpun, menyimpan, dan mengolah arsip menjadi sesuatu yang tumbuh dan berkembang sebagai sumber informasi primer. Sebagai sumber informasi primer selanjutnya dikembangkan dan diolah menjadi informasi untuk disajikan.

Agar informasi tersebut tersaji secara utuh, lengkap, akurat, mutakhir, cepat kepada yang berhak, arsiparis harus juga memguasai struktur organisasi yang menciptakan, menerima, dan memerlukan informasi. Arsiparis harus mampu menyajikan informasi yang berbeda-beda pada saat yang tepat, kepada orang yang benar, dan dalam jumlah yang diperlukan. Perubahan dari peralatan dan aktivitas kearsipan yang "berdebu" menjadi peralatan atau aktivitas kearsipan yang "peka terhadap debu" menuntut revitalisasi peran dan pemberdayaan (empowering) petugas kearsipan (arsiparis). Meskipun pekerjaan kertas masih digunakan, tetapi makna dan fungsinya menjadi berubah tidak hanya sekedar collecting, recording, 
and storing data, tetapi menjadi komponen atau aktivitas elaborator atau forwarder atau data analyst sekaligus manajer informasi.

Petugas kearsipan harus dapat meletakkan aktivitasnya sebagai komponen yang memerlukan profesionalisme tinggi, sehingga dapat mendudukkan profesi arsiparis dalam kategori yang "diperhitungkan" dan menarik. Tidak dipandang sebelah mata seperti sekarang ini. Untuk itu selain persyaratan-persyaratan yang harus dipenuhi sebagai seorang arsiparis seperti: ketrampilan, ketelitian, kerapian, kecerdasan, dan kepribadian, masih perlu ditambah kemampuan untuk menjadi data analyst yang mau tidak mau harus menguasi teknologi informasi dan komunikasi (ICT).

\section{Daftar Pustaka}

Arsip Polda "Berantakan". Kompas, 30 Juni 2005.

Jogiyanto, H.M. 2000. Sistem Informasi Berbasis Komputer: Konsep Dasar dan Komponen. Yogyakarta: BPFE UGM.

Laudon \& Laudon. 1995. Essentials of Management Information Systems: Organization and
Technology. London: PrenticeHall International, Inc.

Noerhadi Magetsari. 1997. "Arsip Sebagai Tulang Punggung Manajemen". Makalah

Seminar Nasional Kearsipan. Yogyakarta: UGM.

The Liang Gie. 1996. Administrasi Perkantoran Modern. Yogyakarta: Penerbit Liberty.

Warsito Utomo. 1997. "Manajemen Sumberdaya Manusia di Bidang Kearsipan."

Makalah Seminar Nasional Kearsipan. Yogyakarta: UGM.

Zulkifli Amsyah, 1998. Manajemen Kearsipan. Jakarta: PT Gramedia Pustaka Utama.

\section{Biodata Penulis}

Sugi Rahayu adalah salah satu staf pengajar di Program Studi Perkantoran Fakultas IImu Sosial Universitas Negeri Yogyakarta 